\title{
Inositol 5'-phosphatase, SHIP1 interacts with phospholipase $C-\gamma 1$ and modulates EGF-induced PLC activity
}

\author{
Minseok Song ${ }^{1}$, Myung Jong $\mathrm{Kim}^{1}$, \\ Sanghoon $\mathrm{Ha}^{1}$, Jong Bae Park ${ }^{1}$, \\ Sung Ho Ryu ${ }^{1}$ and Pann-Ghill Suh ${ }^{1,2}$ \\ ${ }^{1}$ Department of Life Science \\ Division of Molecular and Life Science \\ Postech Biotech Center \\ Pohang University of Science and Technology \\ Pohang 790-784, Republic of Korea \\ ${ }^{2}$ Corresponding author: Tel, 82-54-279-2293; \\ Fax, 82-54-279-2199; E-mail, pgs@postech.ac.kr
}

Accepted 29 April 2005

Abbreviations: DAG, diacylglycerol; EGF, epidermal growth factor; GST, glutathione S-transferase; IP, inositol phosphates; IP3, inositol 1,4,5-trisphosphate; IP4, inositol 1,3,4,5-tetrakisphosphate; PIP2, phosphatidylinositol 4,5-bisphosphate; PIP3, phosphatidylinositol 3,4,5-trisphosphate; PI-3-kinase, phosphtidylinositol-3kinase; PKC, protein kinase C; PLC, phospholipase C; RasGAP, GTPase-activation protein of Ras; $\mathrm{SH}$ domain, Src homology domain; SHIP1, SH2 domain-containing inositol 5'-phosphatase 1

\begin{abstract}
Phospholipase C- $\gamma 1$, containing two SH2 and one $\mathrm{SH} 3$ domains which participate in the interaction between signaling molecules, plays a significant role in the growth factor-induced signal transduction. However, the role of the SH domains in the growth factor-induced PLC- $\gamma 1$ regulation is unclear. By peptide-mass fingerprinting analysis, we have identified SHIP1 as the binding protein for the SH3 domain of PLC- $\gamma 1$. SHIP1 was co-immunoprecipitated with PLC- $\gamma 1$ and potentiated EGF-induced PLC- $\gamma 1$ activation. However, inositol 5 '-phosphatase activity of SHIP1 was not required for the potentiation of EGF-induced PLC-Y1 activation. Taken together, these results suggest that SHIP1 may function as an adaptor protein which can potentiate EGF-induced PLC- $\gamma 1$ activation without regards to its inositol 5'-phosphatase activity.
\end{abstract}

Keywords: epidermal growth factor; phospholipase C- $\gamma 1$; SH2 domain-containing inositol 5'-phosphatase; $\mathrm{SH} 3$ domain

\section{Introduction}

Phospholipase C (PLC) plays a pivotal role in transmembrane signaling. In response to various extracellular stimuli, such as numerous hormones, growth factors, and neurotransmitters, PLC hydrolyzes a minor membrane phospholipid, $\mathrm{PIP}_{2}$, producing the two second messentgers $D A G$ and $\mathbb{I P}_{3}$, which mediate the activation of PKC and intracellular $\mathrm{Ca}^{2+}$ release, respectively (Berridge and Irvine, 1989; Shin et al., 2002). Until now, eleven mammalian isozymes of PLC have been identified and classified into $\beta, \gamma, \delta, \varepsilon$ and $\zeta$ subfamilies based on overall sequence similarities and the conservation of $X$ and $Y$ domains which are essential for the enzymatic activity (Rhee and Bae, 1997; Kim et al., 2000; Song et al., 2001).

Among various isozymes, PLC- $\gamma$ uniquely contains two $\mathrm{SH} 2$ domains and an $\mathrm{SH} 3$ domain between the $\mathrm{X}$ and $Y$ domains (Stahl et al., 1988; Suh et al., 1988). The SH2 domains of PLC- $\gamma 1$ are responsible for the association between PLC- $\gamma 1$ and phosphorylated tyrosine residues on the activated receptor tyrosine kinase. The SH3 domain of PLC- $\gamma 1$ is reported to be important for the mitogenic effect of PLC- $\gamma 1$. Microinjection of the GST-fused $\mathrm{SH} 3$ domain of PLC- $\gamma 1$ into $\mathrm{G}_{0} / \mathrm{G}_{1}$ phasearrested NIH 3 T3 cells has been reported to induce a mitogenic response (Smith et al., 1996). In addition, we have reported that overexpression of the $\mathrm{SH} 2-\mathrm{SH} 2-\mathrm{SH} 3$ domain of PLC- $\gamma 1$ could induce cellular transformation in $3 Y 1$ rat fibroblast and could induce tumor when transplanted into nude mice (Chang et al., 1997). To elucidate the physiological role of $\mathrm{SH} 2-\mathrm{SH} 2-\mathrm{SH} 3$ domains in the function of PLC- $\gamma 1$, it is important to identify $\mathrm{SH} 2-\mathrm{SH} 2-\mathrm{SH} 3$ domain-binding signaling molecules.

In this study, we found SHIP1 as a binding protein for the $\mathrm{SH} 3$ domain of PLC- $\gamma 1$ by pull-down assay with GST-fusion protein. SHIP1 was initially identified as a tyrosine-phosphorylated protein after stimulation of blood cells by any of a broad number of cytokines and growth factors (Damen et al., 1993; Kavanaugh et al., 1994; Lioubin et al., 1994). SHIP1 contains several protein-protein interaction domains, such as a $\mathrm{N}$-terminal $\mathrm{SH} 2$ domain, a potential phosphotyrosine binding domain site, and a C-terminal proline-rich sequences allowing binding of the $\mathrm{SH} 3$ domain (Pesesse et al., 1997). SHIP1 selectively removes the 5'-phosphate from $\mathrm{IP}_{4}$ and $\mathrm{PIP}_{3}$, suggesting that it may act as a downstream of or counter to PI 3-kinase (Damen et al., 1996; Lioubin et al., 1996). As a inositol 5'-phosphatase, SHIP1 is thought to be a negative regulator of PIP3 downstream signal transduction. Indeed, overexpression of SHIP1 can antagonize PI-3-kinase function in Xenopus oocytes (Deuter-Reinhard et al., 1997). Also, SHIP1 is reported to have a role in the negative signaling mediated by the inhibitory receptor FcyRllb 
(Ono et al., 1997). However, it is still unclear whether SHIP1 is involved in growth factor-mediated PLC- $\gamma 1$ activation mechanism.

In this study, we showed the physical association between SHIP1 and the SH3 domain of PLC- $\gamma 1$. Also, EGF-induced PLC- $\gamma 1$ activity was increased by SHIP1 expression without regard to its inositol 5'-phosphatase activity. Our findings suggest the possibility that the domain function of SHIP1 is involved in growth factormediated PLC- $\gamma 1$ activation.

\section{Materials and Methods}

\section{General reagents}

Mammalian cell culture media were purchased from GIBCO-BRL (Gaithersburg, MD). LipofectAMINE was purchased from Invitrogen (Carlsbad, CA). Rabbit polyclonal anti-SHIP1 antibody (\#06-632) was purchased from UBI (Lake Placid, NY). pFLAG-CMV-2 vector, mouse monoclonal anti-FLAG M5 antibody, and antiFLAG M2 agarose were purchased from Eastman Kodak (Rochester, NY). Mouse monoclonal anti-PLC- $\gamma 1$ antibody (F7) was prepared as previously described (Suh et al., 1988). A horseradish peroxidase-conjugated goat anti-rabbit $\lg G$ and goat anti-mouse $\lg A+\lg M+\lg G$ were purchased from Kirkegaard \& Perry Laborotoried (Gaithersburg, MD). Myo-[2-- $\left.{ }^{3} \mathrm{H}\right]$ inositol (18.3 Ci/mmol) were purchased from NEN Life Science Products (Boston, $M A)$. The enhanced Chemiluminescence $(E C L)$ reagent, glutathione-agarose and protein A-agarose were purchased from Amersham Pharmacia International (Buckinghamshire, UK). PMSF, leupeptin, pepstatin A, and aprotinin were obtained from Boehringer Mannheim (Mannheim, Germany). Fetal calf serum and bovine calf serum were purchased from HyClone (Logan, UT). Silver staining kit and Dowex AG 1-X8 formate column were purchased from Bio-rad (Hercules, CA)

\section{Plasmid constructs and mutagenesis}

To generate GST-fusion proteins containing the src homology (SH) domains of PLC- $\gamma 1$, cDNAs encoding the $\mathrm{SH}$ domains were amplified by polymerase chain reaction using rat PLC- $\gamma 1$ CDNA as the template. The mammalian expression vector for FLAG-epitope-tagged PLC- $\gamma 1$ (pFLAG-WT) was made by PCR. The amplified products were inserted in-frame with the FLAG-epitope tag of pFLAG-CMV-2. The mammalian expression vector for mouse SHIP1 (pEBB-HA tagged-wtSHIP1) was a gift from Dr. Kodimangalam S. Ravichandran. And catalytically inactive mutant of SHIP1 was constructed using site-directed mutagenesis.

\section{Expression and purification of GST-fusion proteins}

Recombinant proteins were purified from Escherichia coli strain DH5 containing the appropriate constructs. Expression was induced by IPTG $(0.1 \mathrm{mM})$ for $3-5 \mathrm{~h}$ at $25^{\circ} \mathrm{C}$. Cells were pelleted and resuspended in buffer containing phosphate-buffered saline, $1 \%$ Triton X-100,
$1 \mathrm{mM}$ PMSF, $1 \mu \mathrm{g} / \mathrm{ml}$ leupeptin, $5 \mu \mathrm{g} / \mathrm{ml}$ aprotinin, and $2 \mu \mathrm{M}$ pepstatin $\mathrm{A}$, and then lysed by sonication and clarified by centrifugation at $15,000 \mathrm{~g}$ for $20 \mathrm{~min}$. The soluble fraction was incubated with glutathione-coated Sepharose beads for $3 \mathrm{~h}$ at $4^{\circ} \mathrm{C}$ and then washed 4 times with ice-cold washing buffer $(1 \%$ Triton X-100, $200 \mathrm{mM} \mathrm{NaCl}, 20 \mathrm{mM}$ Tris- $\mathrm{HCl}, \mathrm{pH} 8.0,20 \mathrm{mM} \mathrm{NaF}$, $1 \mathrm{mM}$ PMSF, $1 \mu \mathrm{g} / \mathrm{ml}$ leupeptin, $5 \mu \mathrm{g} / \mathrm{mL}$ aprotinin, and $2 \mu \mathrm{M}$ pepstatin $\mathrm{A}$ ).

\section{in vitro binding experiments}

Clarified lysates $(500 \mu \mathrm{g})$ of SP2 cells were incubated with $5 \mu \mathrm{g}$ of GST-fusion proteins immobilized on glutathione-agarose beads in a final volume of $1 \mathrm{ml}$ of lysis buffer for $2 \mathrm{~h}$ at $4^{\circ} \mathrm{C}$. Protein complexes were collected by centrifugation and washed 4 times with NP40 containing lysis buffer (1\% NP40, $150 \mathrm{mM} \mathrm{NaCl}$, $20 \mathrm{mM}$ Tris- $\mathrm{HCl}, \mathrm{pH} 7.4,20 \mathrm{mM} \mathrm{NaF}, 500 \mu \mathrm{M}$ sodium orthovanadate, $1 \mathrm{mM}$ EDTA, $1 \mathrm{mM}$ PMSF, $1 \mu \mathrm{g} / \mathrm{ml}$ leupeptin, $5 \mu \mathrm{g} / \mathrm{ml}$ aprotinin, and $2 \mu \mathrm{M}$ pepstatin A). Associated protein complexes were dissociated by heating in SDS sample buffer. The protein complexes were resolved by $8 \%$ SDS-PAGE and transferred to a nitrocellulose membrane. SHIP1 was immunoblotted using rabbit anti-SHIP1 antibody. Immunoreactivity was detected using horseradish peroxidase-conjugated secondary antibodies and ECL according to the manufacturer's instructions.

\section{Identifcation of $\mathrm{p} 145$ by protein peptide mass fingerprinting}

The fraction containing p145 after pull-down from SP2 cell was separated on $8 \%$ SDS-PAGE and stained by silver staining kit. The band correspnding to $145 \mathrm{kDa}$ protein were excised, rinsed several times with $3 \%$ methanol and digested with trypsin for $6 \mathrm{~h}$ at $37^{\circ} \mathrm{C}$. Following the extraction of digested peptides from the gel, the extract was lyophilized, resuspended in $100 \mu \mathrm{l}$ of $100 \mathrm{mM}$ ammonium bicarbonate and analyzed by MALDI-TOF (Matrix Associated Laser Desorption Ionization-Time of Flight) mass spectrometry (Perseptive Biosystems, Framingham, MA). Identification of p145 as achieved by database searching program Profound.

\section{Cell culture}

COS-7 cells were maintained in Dulbecco's modified Eagle's medium (DMEM) with $10 \%(\mathrm{v} / \mathrm{v})$ fetal calf serum (FCS), $50 \mathrm{U} / \mathrm{ml}$ penicillin, $50 \mu \mathrm{g} / \mathrm{ml}$ gentamycin sulfate, and $50 \mu \mathrm{g} / \mathrm{ml}$ streptomycin. Cells were plated on cultureware dish and incubated in a humidified $5 \% \mathrm{CO}_{2}$ atmosphere at $37^{\circ} \mathrm{C}$. Cells were seeded at $2 \times 10^{5}$ cells $/ 35 \mathrm{~mm}$ well $24 \mathrm{~h}$ before transfection using liposome-mediated transfection. LipofectAMINE was used for the transfection. We followed the manufacturer's instructions using $1 \mu \mathrm{g}$ of plasmid DNA and $6 \mu \mathrm{l}$ of LipofectAMINE reagent/well, incubated the cells with this mixture for $6 \mathrm{~h}$, and then replaced the medium. Forty-eight hours later, cells were harvested. In the case of serum starvation, transfected cells were serum- 
starved for $18 \mathrm{~h}$ at $30 \mathrm{~h}$ post-transfection.

\section{Co-immunoprecipitation and immunoblotting}

Confluent COS-7 cells in $100 \mathrm{~mm}$ plates were serumstarved in DMEM medium supplemented with only $0.1 \%$ bovine calf serum for $18 \mathrm{~h}$ at $37^{\circ} \mathrm{C}$. Cells were lysed in $1 \mathrm{ml}$ of cold NP40 lysis buffer (1\% NP40, $150 \mathrm{mM}$ $\mathrm{NaCl}, 20 \mathrm{mM}$ Tris-HCl, pH 7.4, $20 \mathrm{mM} \mathrm{NaF}, 500 \mu \mathrm{M}$ sodium orthovanadate, $1 \mathrm{mM}$ EDTA, $1 \mathrm{mM}$ PMSF, 1 $\mu \mathrm{g} / \mathrm{ml}$ leupeptin, $5 \mu \mathrm{g} / \mathrm{ml}$ aprotinin, and $2 \mu \mathrm{M}$ pepstatin A). The cell lysates were clarified by centrifugation at $14,000 \mathrm{~g}$ for $15 \mathrm{~min}$ at $4^{\circ} \mathrm{C}$. The clarified lysates were precleared with $30 \mu \mathrm{l}$ of $50 \%$ protein A-Sepharose for $30 \mathrm{~min}$ at $4^{\circ} \mathrm{C}$. The clarified cell lysates were mixed with $5 \mu \mathrm{g}$ of anti-FLAG antibody immobilized to protein A-Sepharose for $3 \mathrm{~h}$ at $4^{\circ} \mathrm{C}$. The immune complexes were collected by centrifugation (4 $\mathrm{min}$ at $3,000 \mathrm{~g}$ ), washed 4 times with cold NP40 lysis buffer, and dissociated by heating in SDS sample buffer. Proteins were separated by $8 \%$ SDS-PAGE. The separated proteins were then transferred to nitrocellulose filters. Blocking was performed with TTBS buffer [10 mM Tris- $\mathrm{HCl}(\mathrm{pH} 7.6), 150 \mathrm{mM} \mathrm{NaCl}, 0.1 \%$ Tween 20] containing $5 \%$ skim milk powder. The filters were then incubated with anti-HA antibody for $4 \mathrm{~h}$ at room temperature. Immunoblots were subsequently washed and incubated with horseradish peroxidase-linked secondary antibody for $1 \mathrm{~h}$ at room temperature, washed 4 times in TTBS buffer, and developed with horseradish peroxidase-dependent chemiluminescence (ECL).

\section{Measurement of inositol phosphates accumulation}

COS-7 cells were transfected with the cDNA of appropriate constructs. $24 \mathrm{~h}$ after transfection, cells were labeled with $1 \mu \mathrm{ci} / \mathrm{ml}$ myo-[2- $\left.{ }^{3} \mathrm{H}\right]$ inositol in $2.0 \mathrm{ml}$ of inositol free DMEM for $18 \mathrm{~h}$. After washing with medium
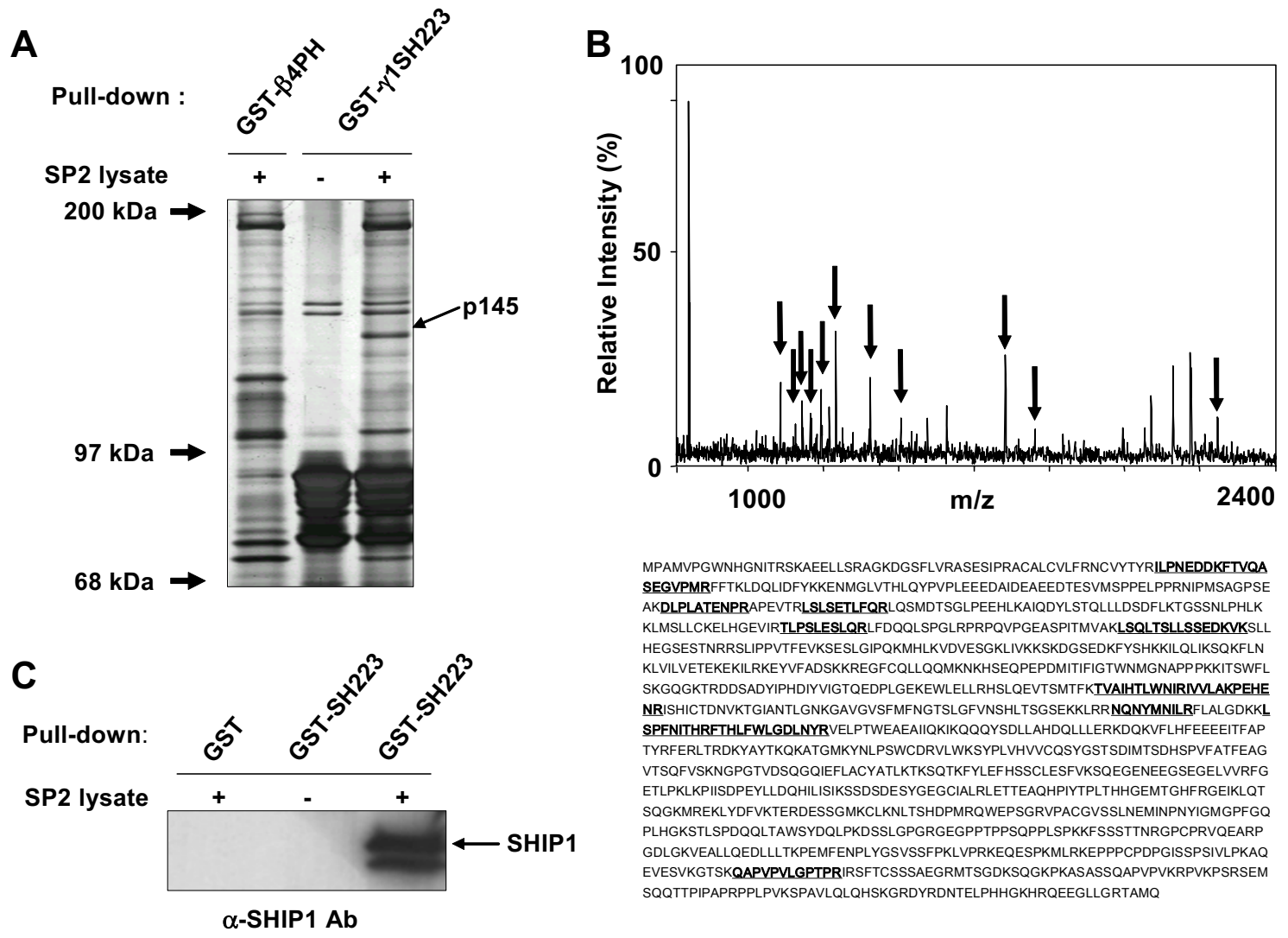

Figure 1. SHIP1 binds to the SH2-SH2-SH3 domain of PLC- $\gamma 1$ in vitro. (A) $500 \mu \mathrm{g}$ of solubilized SP2 cell lysate were subjected to pull-down assay using $5 \mu \mathrm{g}$ of each GST fusion proteins. Precipitates were subjected to SDS-PAGE and resulting polyacrylamide gel were stained with silver reagent. Several specific SH2-SH2-SH3 domain binding proteins were selected and excised. Excised bands were subjected to peptide mass finger printing using MALDI-TOF mass spectrometry. (B) The map was produced by MALDI-TOF mass spectrometry using the peptide supernatant obtained after 'in gel' digestion of the excised band with trypsin as described under "Experimental prodecure". A database search for the measured tryptic peptide masses uniquely identified p145 as SHIP1. Coverage map for SHIP1 were shown and the matching peptides are underlined. (C) The identification of p145 as SHIP1 using MALDI-TOF mass-spectrometry was also confirmed by immunoblotting using anti-SHIP1 antibody. $500 \mu \mathrm{g}$ of SP2 cell lysate were precipitated with $5 \mu \mathrm{g}$ of each GST-fusion proteins immobilized on glutathione-agarose beads. Collected protein complexes were washed with lysis buffer and then subjected to SDS-PAGE. Proteins were transferred to nitrocellurose membrane. Immunoblot analysis was performed with anti-SHIP1 antibody. 
containing $2 \mathrm{mM} \mathrm{LiCl}$ for $10 \mathrm{~min}$, cells were incubated for $10 \mathrm{~min}$ at room temperature with $10 \mathrm{mM}$ EGF in the same medium containing $\mathrm{LiCl}$. The reactions were quenched with $5 \%$ perchloric acid. IP and total inositol fractions were resolved on a Dowex AG 1-X8 formate column.

\section{Results}

\section{SHIP1 binds to the SH2-SH2-SH3 domain of PLC- $\gamma 1$ in vitro}

To elucidate the possible role of $\mathrm{SH} 2-\mathrm{SH}_{2}-\mathrm{SH} 3$ domain-binding proteins in the regulation of PLC- $\gamma 1$, we identified $\mathrm{SH} 2-\mathrm{SH} 2-\mathrm{SH} 3$ domain-binding proteins. SH2$\mathrm{SH} 2-\mathrm{SH} 3$ domain of PLC- $\gamma 1$ was expressed as GST fusion proteins in E.coli and immobilized on GSH agarose. The immobilized GST fusion proteins were incubated with extracts of SP2 cell. Several proteins seemed to specifically interact with $\mathrm{SH} 2-\mathrm{SH} 2-\mathrm{SH} 3$ domain of PLC- $\gamma 1$ in vitro and a protein of apparent molecular mass of $145 \mathrm{kDa}$ ( $\mathrm{p} 145$ ) showed the strongest intensity among $\mathrm{SH} 2-\mathrm{SH} 2-\mathrm{SH} 3$ domain-binding proteins (Figure $1 \mathrm{~A}$ ).

To identify $\mathrm{p} 145$, target band was excised from silver-stained gel and digested with trypsin. Mass spectrometric fingerprinting analysis was performed as described under "Materials and Methods" resulting in the identification of $\mathrm{p} 145$ as $\mathrm{SH} 2$ domain-containing inotitol 5'-phosphatase, SHIP1. A search for these masses in a comprehensive sequence database showed that 11 peptide masses matched to calculated tryptic peptide masses of $\mathrm{SH} 2$ domain-containing 5'-inositol phosphatase, SHIP1 with an accuracy of less than 50 ppm. These peptides covered $12 \%$ of the whole sequence of SHIP1 (Figure 1B). To further verify the identity of $\mathrm{p} 145$, immunoblot analysis was performed using anti-SHIP1 antibody (Figure 1C). Taken together, these data demonstrate that SHIP1 interacts with $\mathrm{SH} 2-\mathrm{SH} 2-\mathrm{SH} 3$ domain of PLC- $\gamma 1$ in vitro.

\section{PLC- $\gamma 1$ interacts with SHIP1 in cells}

In order to further investigate the physical association between SHIP1 and whole PLC- $\gamma 1$ molecule, HA-tagged SHIP1 and FLAG-tagged PLC- $\gamma 1$ were transiently expressed in COS-7 cells. SHIP1 was co-immunoprecipitated with PLC- $\gamma 1$ in resting cells (Figure 2). Both PLC- $\gamma 1$ and SHIP1 are known to be activated by EGF stimulation. However, the physical association between PLC- $\gamma 1$ and SHIP1 was not affected by EGF treatment (data not shown). These results indicate that SHIP1 is associated with whole PLC- $\gamma 1$ molecule in cell.

\section{SHIP1 interacts with SH3 domain of PLC- $\gamma 1$}

To map the region in PLC- $\gamma 1$ which is responsible for the interaction with SHIP1, GST-fused SH domains of PLC- $\gamma 1$ were used in pull-down assay. Purified fusion proteins of various $\mathrm{SH}$ domains were incubated with SP2 cell lysates. SHIP1 was co-precipitated with GST-

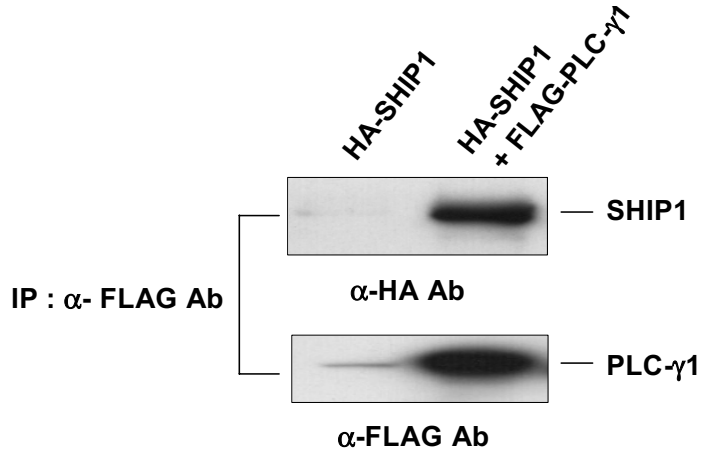

Total cell lysates

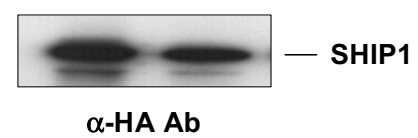

Figure 2. SHIP1 was co-immunoprecipitated with PLC- $\gamma 1$ in COS-7 cell. PLC- $\gamma 1$ and SHIP1 were transiently expressed in COS-7 cells. COS-7 cells were solubilized with lysis buffer and precleared with protein A-Sepharose. Then $500 \mu \mathrm{g}$ of each cell lysate was precipitaed with $5 \mu \mathrm{g}$ of anti-FLAG antibody immobilized to protein A-Sepharose. Resulting precipitates were subjected to SDS-PAGE and immunoblot analysis. Coprecipitation of SHIP1 was checked with anti-HA antibody (upper panel). Precipitated PLC- $\gamma 1$ and expressed SHIP1 were shown using each antibody (middle and lower panel).

SH3 and GST-SH2-SH2-SH3 fusion proteins in vitro, whereas the SHIP1 did not interact with two $\mathrm{SH} 2$ domains of PLC- $\gamma 1$ (Figure 3A).

To further demonstrate the involvement of the $\mathrm{SH} 3$ domain of PLC- $\gamma 1$ in the interaction with SHIP1 in intact cell, we transiently expressed FLAG-tagged wild-type PLC- $\gamma 1$ or mutants PLC- $\gamma 1$ lacking $\mathrm{SH}$ domains with HA-tagged SHIP1 into COS-7 cells. After Serum-starvation, transfected cells were lysed and immunoreacted with anti-FLAG antibody, and resulting precipitates were analyzed with immunoblot analysis using anti-FLAG antibody and anti-HA antibody. SHIP1 was co-immunoprecipitated with wild type and $\mathrm{SH} 2$ domain deletion mutants of PLC- $\gamma 1$ (Figure $3 \mathrm{C}$ ). The deletion of the $\mathrm{SH} 3$ domain from PLC- $\gamma 1$ abolished the interaction with SHIP1. This result shows that SH3 domain of PLC- $\gamma 1$ is necessary for the interaction with SHIP1.

\section{SHIP1 potentiates EGF-induced PLC activation}

SHIP1 was originally identified as an inositol polyphosphate-5-phosphatase in cytokine-stimulated hematopoietic cells (Damen et al., 1996). Also, SHIP1 has an important role in growth factor mediated signaling such as HGF-induced vasiculogenesis in eptithelial cells (Stefan et al., 2001).

The effect of SHIP1 on EGF-induced PLC- $\gamma 1$ activation was tested to investigate the physiological meaning of the interaction between PLC- $\gamma 1$ and SHIP1. EGF is a well-known agonist to activate PLC- $\gamma 1$ in COS-7 cell. COS-7 cells were transfected with HA-tagged SHIP1 or vector plasmid. After $24 \mathrm{~h}$ serum depletion, EGF-induced inositol phosphates generation was mea- 
A

Pull-down : GST SH2N SH2C SH22 SH3 SH223

$\longleftarrow$ SHIP1

$\alpha$-SHIP1 Ab

B

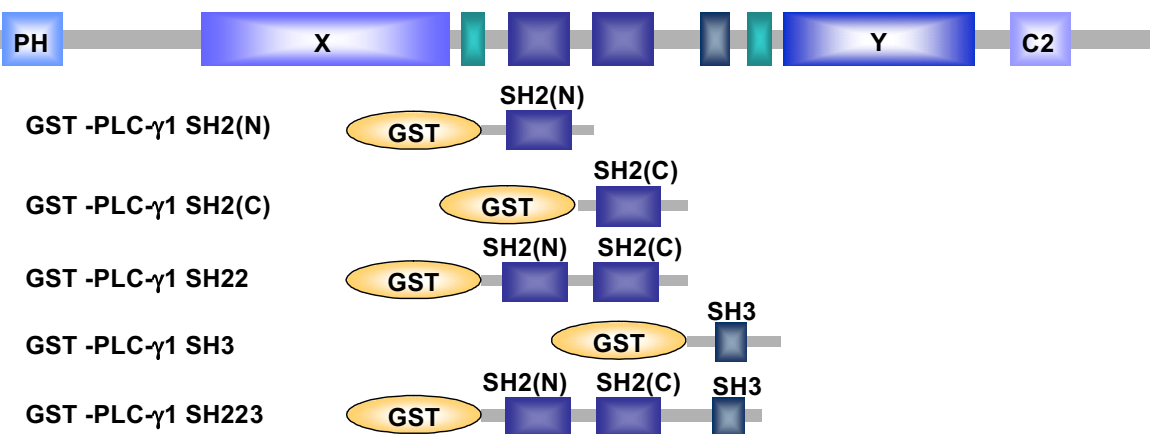

C

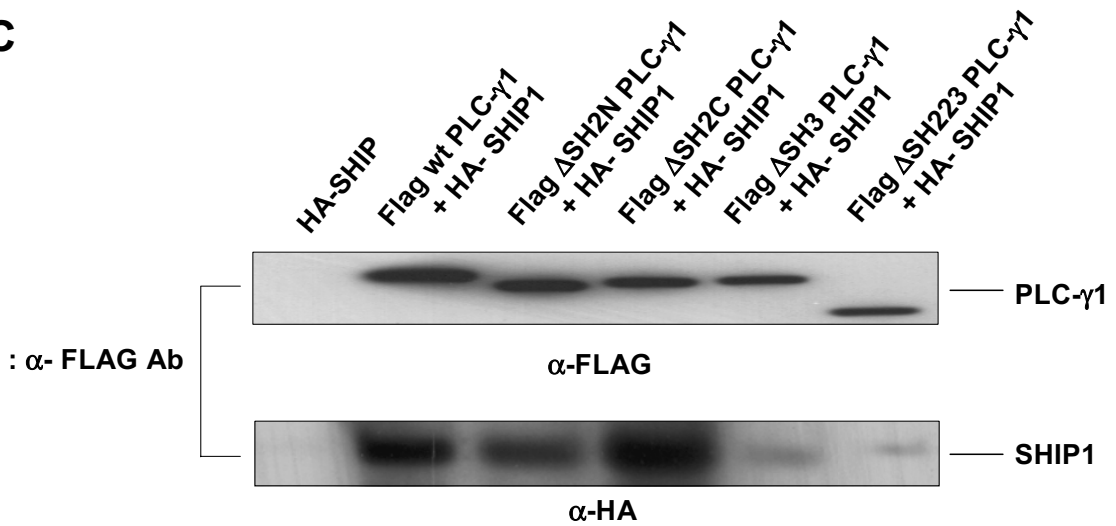

Total cell lysates

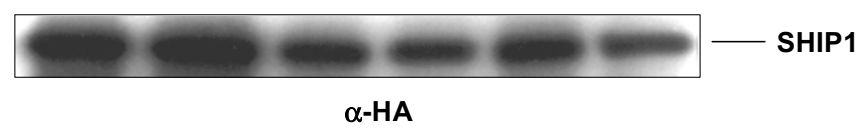

Figure 3. SHIP1 interacts with the $\mathrm{SH} 3$ domain of PLC- $\gamma 1$. (A) Combinations of $\mathrm{SH} 2 \mathrm{~N}, \mathrm{SH} 2 \mathrm{C}, \mathrm{SH} 3$ domain containing GST fusion proteins were constructed and expressed. Pull-down assay was performed using these GST fusion proteins and SP2 cell lysates, and the resulting precipitates were subjected to immunoblot analysis using anti-SHIP1 antibody. As shown above, SHIP1 was precipitated with only GST fusion protein of $\mathrm{SH} 3$ and $\mathrm{SH} 2-\mathrm{SH} 2-\mathrm{SH} 3$ domain of PLC$\gamma 1$. (B) Schematic diagram of various $\mathrm{SH} 2-\mathrm{SH} 2-\mathrm{SH} 3$ domain fusion protein of PLC- $\gamma 1$. (C) COS-7 cells were trasfected with HA-tagged SHIP1/FLAG-tagged wild type or various $\mathrm{SH}$ domain deletion mutant of PLC- $\gamma 1$. After solubilization, resulting lysates was immunoprecipitated with anti-FLAG antibody and analyzed with anti-HA antibody. Total cell lysates $(40 \mu \mathrm{g})$ were also immunoblotted with antiHA antibody.

sured. Basal inositol phosphates level was increased by SHIP1 expression. Also, EGF-induced inositol phosphates generation was increased by 50 percent in cells expressing SHIP1 compared with vector control (Figure 4A) To check whether the 5'-inositol phosphatase activity of SHIP1 is involved in the increase of inositol phosphates generation, catalytically inactive mutant of SHIP1 was used (Deuter-Reinhard et al., 1997). Catalytically inactve mutant of SHIP1 also increase the basal and EGF-induced inositol phosphates generation as those of wild type SHIP1 (Figure 5A). These results indicate that SHIP1 potentiate EGF-induce PLC- $\gamma 1$ activation without regard to its inositol 5'-phosphatase activity. Therefore, these data suggests that the physical interaction between PLC- $\gamma 1$ and SHIP1 might be responsible for the increase of EGF-induced inositol phosphates generation.

\section{Discussion}

Among several molecules involved in growth factormediated signal transduction, PLC- $\gamma 1$ plays a pivotal role for cellular proliferation by growth factor. Not only its lipase activity but also central $\mathrm{SH} 2-\mathrm{SH} 2-\mathrm{SH} 3$ domain of PLC- $\gamma 1$ is thought to be important for the PLC$\gamma 1$-mediated cellular proliferation. Thus, it has become an important issue to identify the proteins that could specifically bind to the SH2-SH2-SH3 domain of PLC$\gamma 1$. Therefore, we set out to find the binding proteins to the SH2-SH2-SH3 domain of PLC- $\gamma 1$ which might participate in PLC- $\gamma 1$-mediated physiological function. In this study, we demonstrated that SHIP1 associates with the SH3 domain of PLC- $\gamma 1$ and potentiates EGF-induced PLC- $\gamma 1$ activation.

SHIP1 has several SH3 domain consensus (PXXP) binding motif in carboxy-terminal which is known to 


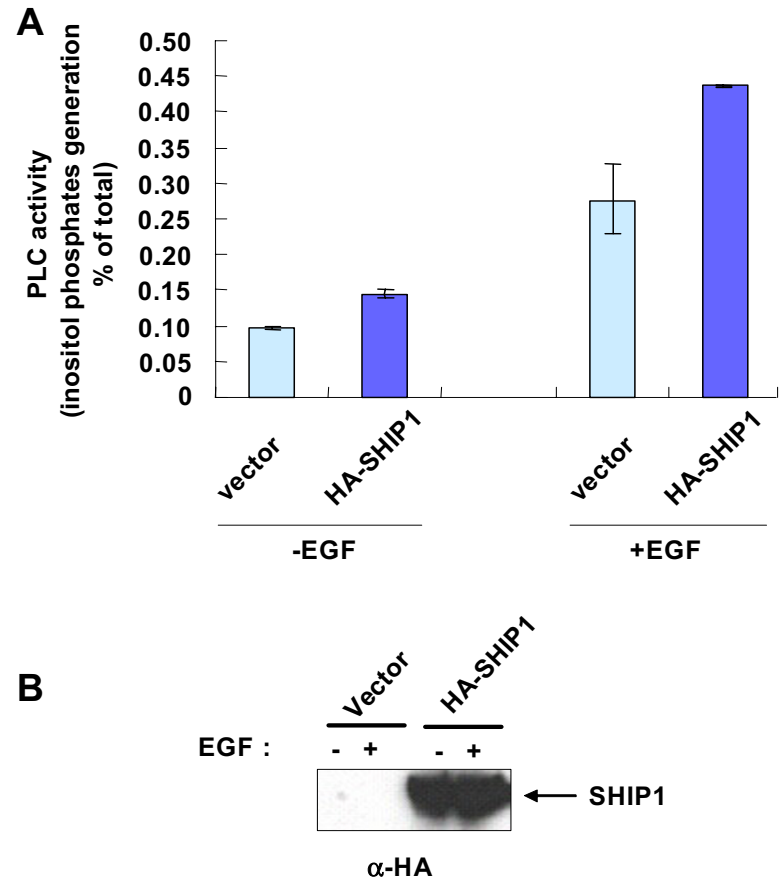

Figure 4. EGF-induced PLC activity is potentiated by SHIP1 expression. (A) COS-7 cells were transfected with vector, wild type of SHIP1 expression vector. $24 \mathrm{~h}$ after transfection, cells were labeled with $1 \mu \mathrm{Ci} / \mathrm{ml}$ myo-[2- $\left.{ }^{3} \mathrm{H}\right]$ inositol in $2 \mathrm{ml}$ of inositol free DMEM for 18 h. Total inositol phosphate accumulation was determined after cells were treated for $10 \mathrm{~min}$ with $100 \mathrm{ng} / \mathrm{ml} \mathrm{EGF}$. Total inositol fractions were resolved on a Dowex AG1-X8 formate column. Data was presented as mean $\pm S$.E. of one of the three experiments performed in duplicate. (B) Expression level of wild type of SHIP1 was shown with anti-HA antibody.

mediate association with $\mathrm{SH} 3$ domains of $\mathrm{Grb} 2$ and $\mathrm{Src}$ (Lucas et al.,1999). Also, we showed that SH3 domain of PLC- $\gamma 1$ was responsible for the association with SHIP1 (Figure 3A, C) and this physical interaction was not changed by EGF stimulation (data not shown). The $\mathrm{SH} 3$ domain, which is not essential for tyrosine phosphorylation, has a role in anchoring $\mathrm{PLC}-\gamma 1$ to the membrane. Although $\mathrm{SH} 2(\mathrm{~N})$ domain is essential for the membrane localization of PLC- $\gamma 1$, SH3 domain may contribute to the membrane attachment of PLC- $\gamma 1$. The SH3 domain of PLC- $\gamma 1$ binds to cytoskeletal components, and translocation of activated PLC- $\gamma 1$ molecules to the detergent-insoluble cell cytoskeleton has been reported (Bar-Sagi et al., 1993; Weng et al., 1993; Pei et al., 1996). Thus, SH3 domain of PLC- $\gamma 1$ may be important for stabilizing the association of PLC- $\gamma 1$ with the membrane through the interaction with cytoskeletal components. As SHIP1 bind to SH3 domain of PLC- $\gamma 1$ in resting state and has to be recruited to EGF receptor for its activation, SHIP1 may function in the membrane translocation process of PLC- $\gamma 1$ through the interaction with $\mathrm{SH} 3$ domain of PLC- $\gamma 1$ like other cytoskeletal components.

SHIP1 is known as a negative regulator of calcium signalling (Choquet et al., 1993; Sarmay et al., 1996;

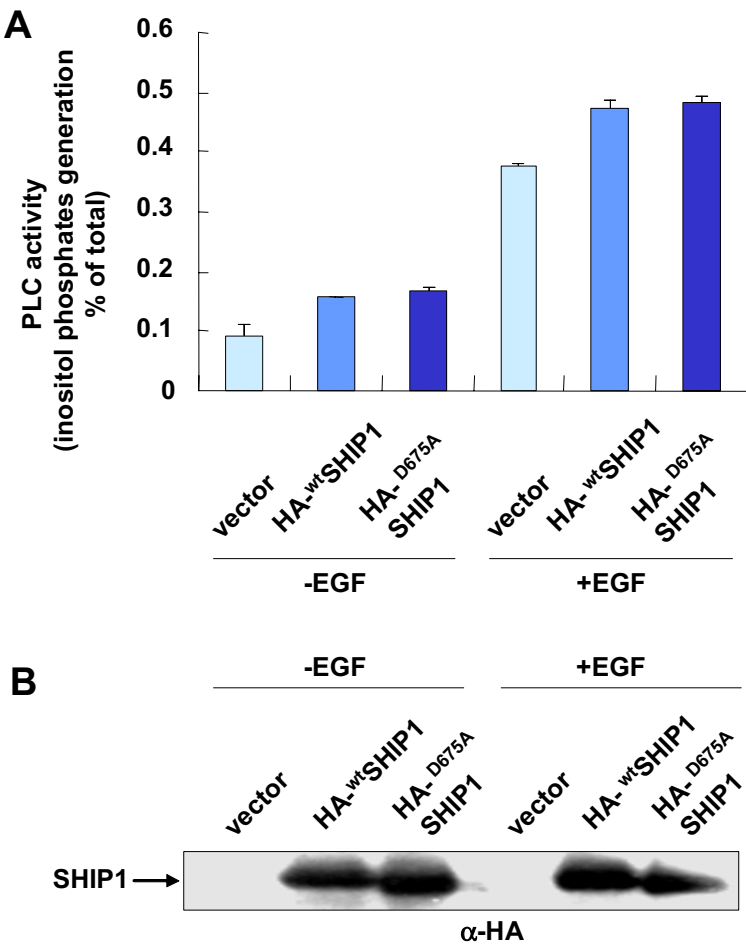

Figure 5. Inositol 5'-phosphatase activity of SHIP1 is not required for the potentiation of EGF-induced PLC activation. (A) COS-7 cells were transfected with vector, wild type or catalytically inactive mutant of SHIP1 expression vector. $24 \mathrm{~h}$ after transfection, cells were labeled with $1 \mu \mathrm{Ci} / \mathrm{ml}$ myo- $\left[2{ }^{3} \mathrm{H}\right]$ inositol in $2 \mathrm{ml}$ of inositol free DMEM for 18 h. Total inositol phosphate accumulation was determined after cells were treated for $10 \mathrm{~min}$ with $100 \mathrm{ng} / \mathrm{ml}$ EGF. Total inositol fractions were resolved on a Dowex AG1-X8 formate column. Data was presented as mean $\pm S$.E. of one of the three experiments performed in duplicate. (B) Expression level of wild type and catalytically inactive mutant of SHIP1 was probed with anti-HA antibody.

Tridandapani et al., 1997). When this gene was knocked out, calcium and $\mathrm{IP}_{3}$ response was not efficiently terminated. And the inositol 5'-phosphatase activity of SHIP1 is believed to be essential in the negative regulation of $\mathrm{IP}_{3}$ generation and calcium release. As PLC- $\gamma 1$ was reported to be activated by $\mathrm{PIP}_{3}$ and EGF activate PI3K in COS-7 cells, we postulated that expression of inositol 5'-phosphatase, SHIP1 will reduce EGF-induced PLC- $\gamma 1$ activation. Not in accordance with our expectation, EGF-induced inositol phosphates generation was potentiated when SHIP1 was transiently expressed in COS-7 cell (Figure 4A). Moreover the inositol 5'-phosphatase activity of SHIP1 was not required for the elavation of EGF-induced inositol phosphate generation (Figure 5A). Potentiation of EGFinduced PLC- $\gamma 1$ activation by SHIP1 expression and dispensibility of inositol 5'-phosphatase activity of SHIP1 for such potentiation implies another role of SHIP1 on growth factor-mediated PLC- $\gamma 1$ activation process. Inositol 5'-phosphatase activity which cleaves 5'-phosphate from PIP3 contribute termination of growth factor-mediated PLC- $\gamma 1$ activation, but SHIP1 may assist PLC- $\gamma 1$ 
activation through the association with $\mathrm{SH} 3$ domain.

Independently of its 5'-phosphatase activity, SHIP1 may function as an adaptor under some circumstances. That suggestion is based on the report that SHIP1 reduces Ras activity by recruiting the RasGAP (GTPase-activation protein of Ras)-binding protein, p62Dok (Tamir et al., 2000). As an adaptor, SHIP1 may support the membrane targeting and phosphorylation of PLC- $\gamma 1$. PLC- $\gamma 1$ is recruited by growth factor receptor, phosphorylated and activated. Also, SHIP1 has to be recruited by growth factor receptor for its function. SHIP1 was associated with PLC- $\gamma 1$ basally, and this association was maintained during EGF-induced activation process. Moreover, expression of catalytically inactive SHIP1 potentiated EGF-induced inositol phosphate generation. Taken together, SHIP1 may function as an adaptor in the activation process of PLC- $\gamma 1$ irrespective of its 5 '-inositol phosphatase activity.

In conclusion, this study demonstrates a novel association of PLC- $\gamma 1$ and the inositol phosphatase SHIP1. By this interaction, PLC- $\gamma 1$ activity potentiated without regards to inositol 5'-phosphatase activity of SHIP1. Also, we suggest another function of SHIP1 as an adaptor protein in the growth factor mediated activation process of PLC- $\gamma 1$.

\section{References}

Bar-Sagi D, Rotin D, Batzer A, Mandiyan V, Schlessinger $\mathrm{J}$. $\mathrm{SH} 3$ domains direct cellular localization of signaling molecules. Cell 1993;74:83-91

Berridge MJ, Irvine RF. Inositol phosphates and cell signalling. Nature 1989;341:197-205

Chang JS, Noh DY, Park IA, Kim MJ, Song H, Ryu SH, Suh PG. Overexpression of phospholipase C-gamma1 in rat $3 Y 1$ fibroblast cells leads to malignant transformation. Cancer Res 1997;57:5465-8

Choquet D, Partiseti M, Amigorena S, Bonnerot C, Fridman WH, Korn $H$. Cross-linking of IgG receptors inhibits membrane immunoglobulin-stimulated calcium influx in B lymphocytes. J Cell Biol 1993;121:355-63

Damen JE, Liu L, Cutler RL, Krystal G. Erythropoietin stimulates the tyrosine phosphorylation of Shc and its association with Grb2 and a $145-\mathrm{Kd}$ tyrosine phosphorylated protein. Blood 1993;82:2296-303

Damen JE, Liu L, Rosten P, Humphries RK, Jefferson AB, Majerus PW, Krystal G. The $145-\mathrm{kDa}$ protein induced to associate with Shc by multiple cytokines is an inositol tetraphosphate and phosphatidylinositol 3,4,5-triphosphate 5phosphatase. Proc Natl Acad Sci USA 1996;93:1689-93

Deuter-Reinhard M, Apell G, Pot D, Klippel A, Williams LT, Kavanaugh WM. SIP/SHIP inhibits Xenopus oocyte maturation induced by insulin and phosphatidylinositol 3-kinase. Mol Cell Biol 1997;17:2559-65

Kavanaugh WM, Williams LT. An alternative to SH2 domains for binding tyrosine-phosphorylated proteins. Science 1994; 266:1862-5
Kim MJ, Kim E, Ryu SH, Suh PG. The mechanism of phospholipase C-gamma1 regulation. Exp Mol Med 2000;32:1019

Lioubin MN, Myles GM, Carlberg K, Bowtell D, Rohrschneider LR. Shc, Grb2, Sos1, and a 150-kilodalton tyrosinephosphorylated protein form complexes with Fms in hematopoietic cells. Mol Cell Biol 1994;14:5682-91

Lioubin MN, Algate PA, Tsai S, Carlberg K, Aebersold A, Rohrschneider LR. p150Ship, a signal transduction molecule with inositol polyphosphate-5-phosphatase activity. Genes Dev 1996;10:1084-95

Lucas DM, Rohrschneider LR. A novel spliced form of SH2containing inositol phosphatase is expressed during myeloid development. Blood 1999;93:1922-33.

Ono M, Okada H, Bolland S, Yanagi S, Kurosaki T, Ravetch JV. Deletion of SHIP or SHP-1 reveals two distinct pathways for inhibitory signaling. Cell 1997;90:293-301

Pei Z, Yang L, Williamson JR. Phospholipase C-gamma 1 binds to actin-cytoskeleton via its $\mathrm{C}$-terminal $\mathrm{SH} 2$ domain in vitro. Biochem Biophys Res Commun 1996;228:802-6

Pesesse X, Deleu S, De Smedt F, Drayer L, Erneux C. Identification of a second SH2-domain-containing protein closely related to the phosphatidylinositol polyphosphate 5phosphatase SHIP. Biochem Biophys Res Commun 1997; 239:697-700.

Rhee SG, Bae YS. Regulation of phosphoinositide-specific phospholipase C isozymes. J Biol Chem 1997;272:15045-8

Sarmay G, Koncz G, Gergely J. Human type II Fcgamma receptors inhibit $B$ cell activation by interacting with the p21(ras)-dependent pathway. J Biol Chem 1996;271:30499504

Shin SY, Yoon SC, Kim YH, Kim YS, Lee YH. Phosphorylation of glycogen synthase kinase-3beta at serine- 9 by phospholipase Cgamma1 through protein kinase $C$ in rat $3 Y 1$ fibroblasts. Exp Mol Med 2002;34:444-50

Smith MR, Liu YL, Kim SR, Bae YS, Kim CG, Kwon KS, Rhee SG, Kung HF. PLC gamma 1 Src homology domain induces mitogenesis in quiescent NIH 3 T3 fibroblasts. Biochem Biophys Res Commun 1996;222:186-93

Song C, Hu CD, Masago M, Kariyai K, Yamawaki-Kataoka $Y$, Shibatohge M, Wu D, Satoh T, Kataoka T. Regulation of a novel human phospholipase C, PLCepsilon, through membrane targeting by Ras. J Biol Chem 2001;276:2752-7

Stahl ML, Ferenz CR, Kelleher KL, Kriz RW, Knopf JL. Sequence similarity of phospholipase $\mathrm{C}$ with the non-catalytic region of src. Nature 1988;332:269-72

Stefan M, Koch A, Mancini A, Mohr A, Weidner KM, Niemann $\mathrm{H}$, Tamura $\mathrm{T}$. Src homology 2-containing inositol 5-phosphatase 1 binds to the multifunctional docking site of c-Met and potentiates hepatocyte growth factor-induced branching tubulogenesis. J Biol Chem 2001;276:3017-23

Suh PG, Ryu SH, Moon KH, Suh HW, Rhee SG. Cloning and sequence of multiple forms of phospholipase $C$. Cell $1988 ; 54: 161-9$

Tamir I, Stolpa JC, Helgason CD, Nakamura K, Bruhns P, Daeron M, Cambier JC. The RasGAP-binding protein p62dok 
is a mediator of inhibitory FcgammaRIIB signals in B cells. Immunity 2000;12:347-58

Tridandapani S, Kelley T, Pradhan M, Cooney D, Justement LB, Coggeshall KM. Recruitment and phosphorylation of SH2-containing inositol phosphatase and Shc to the B-cell Fc gamma immunoreceptor tyrosine-based inhibition motif peptide motif. Mol Cell Biol 1997;17:4305-11

Weng Z, Taylor JA, Turner CE, Brugge JS, Seidel-Dugan C. Detection of Src homology 3-binding proteins, including paxillin, in normal and v-Src-transformed Balb/c $3 T 3$ cells. J Biol Chem 1993;268:14956-63 